\title{
NEAR HYDRATION OF SINGLY CHARGED MONOATOMIC IONS IN EXTREMELY DILUTED SOLUTIONS: THE EFFECT OF TEMPERATURE AND PRESSURE
}

The diffusion coefficient $D_{i}^{0}$ and the distance of translational displacement of $\mathrm{Li}^{+}, \mathrm{Na}^{+} \mathrm{K}^{+}, \mathrm{Cs}^{+}, \mathrm{Cl}^{-}$and $\mathrm{Br}^{-}$ions $\bar{d}$ in water at $298.15 \mathrm{~K}-423.15 \mathrm{~K}$ ( $25 \mathrm{~K}$ step) and pressure from 0.0981 to $784.5 \mathrm{MPa}(98.1 \mathrm{MPa}$ step) were calculated from the literature data on limiting molar electrical conductivity. The $D_{i}^{0}$ values for these ions increase with pressure growth from 0.0981 to $98.1 \mathrm{MPa}$ at $298.15 \mathrm{~K}$. Further pressure increase (up to $785 \mathrm{MPa}$ ) leads to decrease in $D_{i}^{0}$. Temperature growth under isobaric conditions leads to an increase in $D_{i}^{0}$. Parameter $\left(\bar{d}-r_{i}\right)$ (deviation from the Stokes-Einstein law, $r_{i}$ is ion structural radius) was used as a criterion for the type of ion solvation. It is shown that $\mathrm{Li}^{+}$and $\mathrm{Na}^{+}$ions behave as cosmotropes, or positively solvated structure-forming ions having $\left(\bar{d}-r_{i}\right)>0$. The $\mathrm{Cs}^{+}, \mathrm{Cl}^{-}, \mathrm{Br}^{-}$ions behave as chaotropes, or negatively solvated structure-breaking ions having $\left(\bar{d}-r_{i}\right)<0$. For the $\mathrm{K}^{+}$ion, the $\left(\bar{d}-r_{i}\right)$ deviation is alternating. At $0.0981 \mathrm{MPa}$ and $298.15 \mathrm{~K}$, the $\mathrm{K}^{+}$ion is a chaotrope. But at $320 \mathrm{~K}$ $\left(T_{\lim }\right)$ parameter $\left(\bar{d}-r_{i}\right)=0$. It corresponds to the transition from negative to positive solvation. Above $T_{\lim }$ at $P=$ const, the $\mathrm{K}^{+}$ion is a cosmotrope. At $298.15 \mathrm{~K}$ and up to $98.1 \mathrm{MPa}$, the pressure causes the same change in the $\left(\bar{d}-r_{i}\right)$ deviation as the temperature. On the contrary, at $320 \mathrm{~K}$ and higher, the pressure affects the near hydration in the direction opposite to the temperature.

Keywords: monoatomic ions, diffusion, diffusion displacement length, positive and negative solvation

\section{В.І. БУЛАВІН, І.М. В'ЮНИК, А.В. КРАМАРЕНКО, О.І.РУСІНОВ}

\section{БЛИЖНЯ ГІДРАТАЦІЯ ОДНОЗАРЯДНИХ ОДНОАТОМНИХ ІОНІВ У ГРАНИЧНО РОЗБАВЛЕНИХ РОЗЧИНАХ: ВПЛИВ ТЕМПЕРАТУРИ ТА ТИСКУ}

Коефіцієнт дифузії $D_{i}^{0}$ та довжина дифузійного зміщення $\bar{d}$ іонів $\mathrm{Li}^{+}, \mathrm{Na}^{+} \mathrm{K}^{+}, \mathrm{Cs}^{+}, \mathrm{Cl}^{-}$and $\mathrm{Br}^{-}$у воді при $298,15 \mathrm{~K}-423,15 \mathrm{~K}$ (шаг $25 \mathrm{~K}$ ) і тиску від 0,0981 до 784,5 МПа (шаг 98,1 МПа) розраховані на підставі літературних даних щодо їх граничної молярної електричної провідності. Величини $D_{i}^{0}$ цих іонів зростають при 298,15 К зі збільшенням тиску від 0,0981 до 98,1 МПа. Подальше підвищення тиску до 785 МПа призводить до зменшення $D_{i}^{0}$. Зростання температури в ізобаричних умовах призводить до збільшення $D_{i}^{0}$. Параметр $\left(\bar{d}-r_{i}\right)$ (відхилення від закону Стокса-Ейнштейна, $r_{i}$ - структурний радіус іона) використаний як критерій типу сольватації іонів. Показано, що іони $\mathrm{Li}^{+}$i Na${ }^{+}$ведуть себе як космотропи, або позитивно сольватовані структуроутворюючі іони, для яких $\left(\bar{d}-r_{i}\right)>0 . \mathrm{IoHи}^{-} \mathrm{Cs}^{+}, \mathrm{Cl}^{-}$i $\mathrm{Br}^{-}-$ хаотропи, або негативно сольватовані структуро-руйнуючі іони для яких $\left(\bar{d}-r_{i}\right)<0$. Для іона $\mathrm{K}^{+}$параметр $\left(\bar{d}-r_{i}\right) \epsilon$ знакозмінним. При 0,0981 МПа та $298,15 \mathrm{~K}$ іон $\mathrm{K}^{+}$- хаотроп, але при $320 \mathrm{~K}\left(T_{\text {тран})}\right)$ величина $\left(\bar{d}-r_{i}\right)=0$. Це відповідає переходу від негативної до позитивної сольватації. Вище $\mathrm{T}_{\text {гран }}$ при $P=$ const іон $\mathrm{K}^{+} \epsilon$ космотропом. При $298,15 \mathrm{~K}$ і до 98,1 МПа тиск спричиняє таку ж зміну $\left(\bar{d}-r_{i}\right)$, як $\mathrm{i}$ температура. При 320 К і вище тиск впливає на ближню гідратацію у напрямку, протилежному дії температури.

Ключові слова: одноатомні іони, дифузія, довжина дифузійного зміщення, негативна сольватація

\section{В.И. БУЛАВИН, И.Н. ВЬЮННИК, А.В. КРАМАРЕНКО, А.И. РУСИНОВ \\ БЛИЖНЯЯ ГИДРАТАЦИЯ ОДНОЗАРЯДНЫХ ОДНОАТОМНЫХ ИОНОВ В ПРЕДЕЛЬНО РАЗБАВЛЕННЫХ РАСТВОРАХ: ВЛИЯНИЕ ТЕМПЕРАТУРЫ И ДАВЛЕНИЯ}

Коэффициент диффузии $D_{i}^{0}$ и длина трансляционного смещения $\bar{d}$ ионов $\mathrm{Li}^{+}, \mathrm{Na}^{+} \mathrm{K}^{+}, \mathrm{Cs}^{+}, \mathrm{Cl}^{-}$и $\mathrm{Br}^{-}$в воде при $298,15 \mathrm{~K}^{-} 423,15 \mathrm{~K}^{2}$ шаг 25 К) и давлении $(P)$ 0,0981 -784,5 МПа (шаг 98,1 МПа) рассчитаны из литературных данных по предельной молярной электрической проводимости этих ионов. Значения $D_{i}^{0}$ при 298,15 К с повышением $P$ от 0,0981 до 98,1 МПа увеличиваются, при возрастании давления от 98,1 до 785 МПа уменьшаются. При Т > 298,15 К с увеличением давления $D_{i}^{0}$ этих ионов уменьшается. Повышение температуры в изобарических условиях приводит к возрастанию $D_{i}^{0}$. Критерием типа сольватации ионов использован знак отклонения от закона Стокса-

(C) V.I. Bulavin, I.N. Vyunnik, A.V. Kramarenko, A.I. Rusinov, 2021 
Эйнштейна $\left(\bar{d}-r_{i}\right)$, где $r_{i}-$ структурный радиус иона. Ионы $\mathrm{Li}^{+}$и $\mathrm{Na}^{+}-$космотропы (положительно сольватированные $\left(\left(\bar{d}-r_{i}\right)>0\right)$ ионыструктурообразователи), ионы $\mathrm{Cs}^{+}, \mathrm{Cl}^{-}, \mathrm{Br}^{--}$хаотропы (отрицательно сольватированные $\left(\left(\bar{d}-r_{i}\right)<0\right)$ ионы - разрушители структуры). Для иона $\mathrm{K}^{+}$параметр $\left(\bar{d}-r_{i}\right)$ знакопеременный. При $P=0,0981$ МПа и $T=298,15 \mathrm{~K}\left(\bar{d}-r_{i}\right)<0-$ ион $\mathrm{K}^{+}-$хаотроп. При 320 К $\left(T_{\text {пред}}\right)$ величина $\left(\bar{d}-r_{i}\right)=0$. Выше $T_{\text {пред }}$ при $P=$ const ион $\mathrm{K}^{+-}$космотроп. При 298,15 К и $P$ до 98,1 МПа давление влияет на изменение $\left(\bar{d}-r_{i}\right)$, как и температура. При 320 К и выше действие $P$ противоположно действию температуры.

Ключевые слова: одноатомные ионы, диффузия, длина диффузионного смещения, отрицательная сольватация

Introduction. The study of ion solvation is one of the most important problems in the chemistry of electrolyte solutions. Both the near and far surroundings of the ion changes in the process of ionic solvation. Many properties of ions and their effect on the solvent can be explained using the concept of solvation. In studying the effect of ions on the dynamics of the closest solvent molecules, the greatest success was achieved in the study of aqueous solutions. According to the effect on the water structure, Samoilov [1] divided the ions into two groups:

1) ions solvated positively $\left(\Delta E_{i}=E_{1}-E_{2}>0\right.$, $\left.\tau_{i} / \tau>1\right)$;

$2)$ ions solvated negatively $\left(\Delta E_{i}=E_{1}-E_{2}<0\right.$, $\left.\tau_{i} / \tau<1\right)$.

Samoilov [1] includes structure-making ions in the first group, and structure-breaking ions in the second group. In the development of Samoilov's views, Collins [2] (in the model of soldered spheres) proposed later the "cosmotropes" term for structure-makers. They are singly charged ions of small size (having a high charge density that firmly binds water molecules). Correspondingly, the "chaotropes" are the structure-breakers, or singly charged ions of large size having a low charge density. They bind water molecules weaker than the latter bind each other.

Today highly structured water and aqueous solutions have been studied most fully [3-6]. To study short-range solvation [3] in water, the most modern methods are involved, including molecular dynamics modeling (MDM). As a result, significant progress has been achieved, new models and mechanisms have been proposed [4-6]. At the same time, many questions are still not sufficiently developed.

Modern technologies and theories determine the conduct of research in a wide range of state parameters. However, the lack of fundamental information on the properties of water and ions in aqueous solutions in a wide range of temperatures and pressures does not allow one to predict even qualitatively the effect of pressure on the short-range hydration of ions. Known experimental data [7-11] in terms of the effect of pressure on the dynamics of water molecules closest to the ion are limited both by the range of pressures and temperatures, and by the set of electrolytes. The conclusions of these works are contradictory $[7,8,10,12]$. Samoilov and co-workers [7, 8], based on the data on the density of dilute aqueous solutions of $\mathrm{NaCl}, \mathrm{KCl}$ and $\mathrm{NH}_{4} \mathrm{Cl}$, came to the conclusion that with an increase in pressure from 0.1014 to $101.4 \mathrm{MPa}$ the near hydration of $\mathrm{Na}^{+}$and $\mathrm{K}^{+}$ions increases due to the destruction of the water structure,. For the $\mathrm{NH}_{4}{ }^{+}$ion, the close-range solvation characteristic passes through a minimum. Nakahara [11], calculating the number of hydration of ions in an infinitely dilute solution of $\mathrm{KCl}$ at $288.15,298.15$ and $313.15 \mathrm{~K}$ and pressures from 0.1014 to $507 \mathrm{MPa}$, showed that they practically do not change with increasing pressure for $\mathrm{K}^{+}$and $\mathrm{Cl}^{-}$ions.

According to Horn [10], an increase in pressure leads not only to the destruction of the intrinsic structure of water in solution, but also to a weakening of near hydration. Toryanik [12] came to the conclusion that ions, as well as temperature and pressure, have a destructive effect on water. He based on the results of a study of the water molecules diffusion coefficient in solutions of lithium, sodium, potassium and cesium chlorides over the temperature range $263-343 \mathrm{~K}$ and pressures up to $0.7 \mathrm{GPa}$.

It seems interesting to use the developed in [13, 14] and well-proven approach to determining the criteria for positive $\left(\bar{d}-r_{i}\right)>0$ and negative $\left(\bar{d}-r_{i}\right)<0$ ion solvation. It based on the deviation from the StokesEinstein law in the form of a difference $\left(\bar{d}-r_{i}\right)$ and reflects the effect of temperature and pressure on the short-range hydration of monatomic ions.

The choice of the difference $\left(\bar{d}-r_{i}\right)$ between the distance $\bar{d}$ of the translational displacement of an ion and its structural radius $r_{i}$ as a measure of the effect on the mobility of the closest solvent molecules was substantiated in [14].

Results. In this work, the diffusion coefficient and the translational displacement distance for $\mathrm{Li}^{+}, \mathrm{Na}^{+} \mathrm{K}^{+}$, $\mathrm{Cs}^{+}, \mathrm{Cl}^{-}$and $\mathrm{Br}^{-}$ions in water at $298.15 \mathrm{~K}-423.15 \mathrm{~K}$ (step $25 \mathrm{~K}$ ) are calculated from the data on the limiting molar electrical conductivity of ions $\left(\lambda_{i}^{0}\right)$ and pressures from 0.0981 to $784.5 \mathrm{MPa}$ (step 98.1 MPa). The values and were calculated using the Nernst-Einstein (1) and Stokes- 
Einstein (2) equations, respectively:

$$
\begin{aligned}
& D_{i}^{0}=\frac{R T}{\left|z_{i}\right| F^{2}} \lambda_{i}^{0} \\
& \bar{d}=\frac{k T}{6 \pi D_{i}^{0} \eta_{0}}
\end{aligned}
$$

In equations (1) and (2) $T$ is the temperature, $K ; R$ is the molar gas constant; $k$ is the Boltzmann constant; $z_{i}$ is the charge of the ion; $F$ is the Faraday number, $\eta_{0}$ is the dynamic viscosity of the solvent. The quantities and $\eta_{0}$ necessary for the calculation by equations (1) and (2) are taken from $[15,16]$.

The calculated values of the diffusion coefficient and $\left(\bar{d}-r_{i}\right)$ parameter for six singly charged ions in water (at the temperatures and pressures indicated above) are presented in Tables 1 and 2 . When calculating the $\left(\bar{d}-r_{i}\right)$ difference, we used the structural radii of ions according to Goldschmidt (in $\AA$ ) : $\mathrm{Li}^{+}=0,78 ; \mathrm{Na}^{+}=0.98 ; \mathrm{K}^{+}=1.33$, $\mathrm{Cs}^{+}=1.65 ; \mathrm{Cl}^{-}=1.81 ; \mathrm{Br}^{-}=1.96$ [17].

Table 1 data analysis show that at $298.15 \mathrm{~K}$ the value of the diffusion coefficient of the studied ions in water increases while the pressure growing from 0.0981 to $98.1 \mathrm{MPa}$. Further increase in pressure up to $785 \mathrm{MPa}$ leads to the diffusion coefficient diminishing (Fig. 1). At temperatures above $298.15 \mathrm{~K}$, it also decreases with an increase in the pressure (Table 1). An increase in temperature under isobaric conditions $(P=$ const $)$ leads to an increase in $D_{i}^{0}$ values.

This pressure influence on the diffusion coefficient at $298.15 \mathrm{~K}$ can be explained by water viscosity change [15] (Table 3). In the range of 0.0981-98.1 MPa, the viscosity of water decreases with increasing pressure, but it increases with further pressure growth. With an increase in temperature at $P=$ const, the viscosity of water decreases (Table 3).

From the analysis of polybaric and polythermal $(\bar{d}-$ $r_{i}$ ) dependences (Table 2; Fig. 2-4), the following conclusions can be drawn:

1. $\mathrm{Li}^{+}$and $\mathrm{Na}^{+}$ions over the investigated temperature range $298.15-423.15 \mathrm{~K}$ and pressures $0.0981-784.5 \mathrm{MPa}$ behave like kosmotropes $\left(\left(\bar{d}-r_{i}\right)>0\right)$. It indicates the positive hydration. It weakens with pressure growth $\left(\partial\left(\bar{d}-r_{i}\right) / \partial P<0\right)$ at the temperatures studied. Under isobaric conditions, as the temperature rises, the positive hydration of the $\mathrm{Li}^{+}$cation weakens $\left(\partial\left(\bar{d}-r_{i}\right) / \partial P<0\right)$, while that of the $\mathrm{Na}^{+}$cation slightly increases $\left(\partial\left(\bar{d}-r_{i}\right) / \partial P>0\right)$.

2. $\mathrm{Cs}^{+}, \mathrm{Cl}^{-}, \mathrm{Br}^{-}$ions in the investigated temperature and pressure range behave as chaotropes $\left(\bar{d}-r_{i}\right)<0$, which indicates negative solvation, which under isothermal conditions increases with increasing pressure, while in isobaric $(P=$ const $)$ decreases with increasing temperature $\partial\left(\bar{d}-r_{i}\right) / \partial P>0$.

3. The most interesting turned out to be the behavior of the $\mathrm{K}^{+}$ion with a change in $T$ and $P$. At a saturated vapor pressure $\left(P_{\text {sat }}\right)$ and $T=298.15 \mathrm{~K}$, this cation behaves like a chaotrope $\left(\bar{d}-r_{i}\right)<0$. As the temperature rises, the value $\left(\bar{d}-r_{i}\right)$ increases and at $320 \mathrm{~K}$ it reaches zero. This temperature corresponds to the transition from negative to positive solvation $\left(T_{\lim }=320 \mathrm{~K}\right)$. Above $T_{\lim }$ at $P=$ const, the $\mathrm{K}^{+}$ion behaves like a kosmotrope (Fig. 2). At $T=298.15 \mathrm{~K}$, an increase in pressure leads to a decrease in $\left(\bar{d}-r_{i}\right)$ parameter, which corresponds to an increase in negative solvation (Fig. 3). Polytherms $(\bar{d}-$ $\left.r_{i}\right)-\mathrm{T}$ (shown in fig. 2,3) and polybars $\left(\bar{d}-r_{i}\right)-\mathrm{P}$ indicate the opposite influence of $T$ and $P$ on the shortrange solvation of the $\mathrm{K}^{+}$cation in water. The intersection of polytherms and polybars with a zero line allows us to determine the limiting temperatures $\left(T_{\mathrm{lim}}\right)$ and limiting pressures $\left(P_{\text {lim }}\right)$ of the transition from negative to positive hydration. They are given in Table. 4.5. The transition from negative to positive hydration is also observed for the $\mathrm{Rb}^{+}$cation (Fig. 4), for which $T_{\text {lim. }}$ is $387 \mathrm{~K}$ at saturated vapour pressure.

4. From the analysis of polytherms and polybar of $\left(\bar{d}-r_{i}\right)$ parameter it follows that the $\mathrm{K}^{+}$cation behaves like a chaotrope at $298.15 \mathrm{~K}$ regardless of $P$ in the pressure range 0.0981-784.5 $\mathrm{MPa}$ (Fig. 3). At temperatures from $298.15 \mathrm{~K}$ to $423.15 \mathrm{~K}$, the chaotropic properties of the $\mathrm{K}^{+}$ion are retained at pressures above 588.6 MPa. At a temperature of $320 \mathrm{~K}$ and higher, the pressure acts on the near hydration in the direction opposite to the temperature. At $298.15 \mathrm{~K}$ and pressures up to $98.1 \mathrm{MPa}$, the pressure causes the same change $\left(\bar{d}-r_{i}\right)$ as the temperature. Thus, the opinion existing in the literature $[18,19]$ that pressure and temperature act on the structure of water in the same direction is valid in the pressure range up to $98.1 \mathrm{MPa}$ at $\mathrm{T} \leq 320 \mathrm{~K}$. At higher parameters of state, $T$ and $P$ have the opposite effect on near solvation. 
Table 1. - Ions diffusion coefficient $D_{i}^{0}$ values at different temperatures and pressures

\begin{tabular}{|c|c|c|c|c|c|c|c|c|c|c|c|c|}
\hline \multirow{3}{*}{$\begin{array}{c}\mathrm{P} \\
\mathrm{MPa}\end{array}$} & \multicolumn{12}{|c|}{$D_{i}^{0} \cdot 10^{9}, \mathrm{~m}^{2} \cdot \mathrm{s}^{-1}$} \\
\hline & \multicolumn{6}{|c|}{$298,15 \mathrm{~K}$} & \multicolumn{6}{|c|}{$323,15 \mathrm{~K}$} \\
\hline & $\mathrm{Li}^{+}$ & $\mathrm{Na}^{+}$ & $\overline{\mathrm{K}^{+}}$ & $\mathrm{Cs}^{+}$ & $\mathrm{Cl}^{-}$ & $\mathrm{Br}^{-}$ & $\mathrm{Li}^{+}$ & $\mathrm{Na}^{+}$ & $\mathrm{K}^{+}$ & $\mathrm{Cs}^{+}$ & $\overline{\mathrm{Cl}^{-}}$ & $\mathrm{Br}^{-}$ \\
\hline 0,0981 & 1,028 & 1,334 & 1,960 & 2,053 & 2,034 & 2,082 & 1,815 & 2,303 & 3,221 & 3,316 & 3,377 & 3,443 \\
\hline 98,1 & 1,055 & 1,369 & 2,011 & 2,096 & 2,090 & 2,141 & 1,787 & 2,266 & 3,175 & 3,270 & 3,339 & 3,403 \\
\hline 196,1 & 1,025 & 1,331 & 1,957 & 2,048 & 2,040 & 2,088 & 1,729 & 2,194 & 3,077 & 3,181 & 3,247 & 3,302 \\
\hline 294,2 & 0,985 & 1,281 & 1,885 & 1,981 & 1,973 & 2,013 & 1,662 & 2,107 & 2,964 & 3,074 & 3,134 & 3,186 \\
\hline 392,3 & 0,937 & 1,217 & 1,797 & 1,899 & 1,883 & 1,920 & 1,587 & 2,012 & 2,837 & 2,955 & 3,010 & 3,059 \\
\hline 490,3 & 0,887 & 1,148 & 1,699 & 1,805 & 1,787 & 1,819 & 1,512 & 1,914 & 2,707 & 2,834 & 2,880 & 2,915 \\
\hline 588,4 & 0,831 & 1,076 & 1,598 & 1,710 & 1,686 & 1,710 & 1,432 & 1,813 & 2,563 & 2,704 & 2,742 & 2,771 \\
\hline 686,5 & 0,778 & 1,007 & 1,499 & 1,614 & 1,584 & 1,603 & 1,354 & 1,712 & 2,430 & 2,574 & 2,603 & 2,624 \\
\hline 784,5 & 0,727 & 0,937 & 1,401 & 1,523 & 1,489 & 1,502 & 1,276 & 1,611 & 2,295 & 2,448 & 2,465 & 2,479 \\
\hline \multirow{3}{*}{$\begin{array}{c}\mathrm{P} \\
\mathrm{MPa}\end{array}$} & \multicolumn{12}{|c|}{$D_{i}^{0} \cdot 10^{9}, \mathrm{~m}^{2} \cdot \mathrm{s}^{-1}$} \\
\hline & \multicolumn{6}{|c|}{$348,15 \mathrm{~K}$} & \multicolumn{6}{|c|}{$373,15 \mathrm{~K}$} \\
\hline & $\mathrm{Li}^{+}$ & $\mathrm{Na}^{+}$ & $\mathrm{K}^{+}$ & $\mathrm{Cs}^{+}$ & $\mathrm{Cl}^{-}$ & $\mathrm{Br}^{-}$ & $\mathrm{Li}^{+}$ & $\mathrm{Na}^{+}$ & $\mathrm{K}^{+}$ & $\mathrm{Cs}^{+}$ & $\mathrm{Cl}^{-}$ & $\mathrm{Br}^{-}$ \\
\hline 0,0981 & 2,855 & 3,545 & 4,761 & 4,854 & 5,037 & 5,109 & 4,129 & 5,022 & 6,532 & 6,619 & 6,962 & 7,015 \\
\hline 98,1 & 2,743 & 3,405 & 4,586 & 4,692 & 4,879 & 4,935 & 3,969 & 4,836 & 6,296 & 6,406 & 6,749 & 6,792 \\
\hline 196,1 & 2,652 & 3,290 & 4,443 & 4,555 & 4,739 & 4,785 & 3,773 & 4,589 & 5,996 & 6,132 & 6,452 & 6,486 \\
\hline 294,2 & 2,531 & 3,137 & 4,248 & 4,378 & 4,546 & 4,583 & 3,583 & 4,359 & 5,706 & 5,866 & 6,175 & 6,192 \\
\hline 392,3 & 2,407 & 2,982 & 4,045 & 4,192 & 4,347 & 4,372 & 3,416 & 4,156 & 5,462 & 5,632 & 5,929 & 5,939 \\
\hline 490,3 & 2,295 & 2,842 & 3,865 & 4,024 & 4,170 & 4,185 & 3,259 & 3,963 & 5,212 & 5,412 & 5,689 & 5,686 \\
\hline 588,4 & 2,183 & 2,702 & 3,685 & 3,856 & 3,980 & 3,993 & 3,106 & 3,769 & 4,966 & 5,186 & 5,446 & 5,432 \\
\hline 686,5 & 2,062 & 2,553 & 3,489 & 3,672 & 3,790 & 3,790 & 2,960 & 3,586 & 4,749 & 4,986 & 5,222 & 5,192 \\
\hline 784,5 & 1,954 & 2,413 & 3,302 & 3,507 & 3,604 & 3,598 & 2,820 & 3,416 & 4,526 & 4,776 & 4,992 & 4,952 \\
\hline
\end{tabular}

\begin{tabular}{|c|c|c|c|c|c|c|c|c|c|c|c|c|}
\hline \multirow{3}{*}{$\begin{array}{c}\mathrm{P}, \\
\mathrm{MPa}\end{array}$} & \multicolumn{12}{|c|}{$D_{i}^{0} \cdot 10^{9}, \mathrm{~m}^{2} \cdot \mathrm{s}^{-1}$} \\
\hline & \multicolumn{6}{|c|}{$398,15 \mathrm{~K}$} & \multicolumn{6}{|c|}{$423,15 \mathrm{~K}$} \\
\hline & $\mathrm{Li}^{+}$ & $\mathrm{Na}^{+}$ & $\mathrm{K}^{+}$ & $\mathrm{Cs}^{+}$ & $\mathrm{Cl}^{-}$ & $\mathrm{Br}^{-}$ & $\mathrm{Li}^{+}$ & $\mathrm{Na}^{+}$ & $\mathrm{K}^{+}$ & $\mathrm{Cs}^{+}$ & $\mathrm{Cl}^{-}$ & $\mathrm{Br}^{-}$ \\
\hline 0,0981 & 5,661 & 6,771 & 8,545 & 8,641 & 9,171 & 9,182 & 7,347 & 8,655 & 10,65 & 10,78 & 11,49 & 11,44 \\
\hline 98,1 & 5,338 & 6,383 & 8,086 & 8,218 & 8,734 & 8,723 & 6,893 & 8,114 & 10,03 & 10,20 & 10,91 & 10,83 \\
\hline 196,1 & 5,014 & 5,999 & 7,624 & 7,795 & 8,286 & 8,257 & 6,478 & 7,623 & 9,452 & 9,675 & 10,36 & 10,25 \\
\hline 294,2 & 4,786 & 5,722 & 7,290 & 7,493 & 7,958 & 7,912 & 6,122 & 7,203 & 8,961 & 9,222 & 9,872 & 9,747 \\
\hline 392,3 & 4,570 & 5,462 & 6,970 & 7,197 & 7,645 & 7,585 & 5,809 & 6,833 & 8,519 & 8,813 & 9,441 & 9,305 \\
\hline 490,3 & 4,328 & 5,167 & 6,618 & 6,870 & 7,290 & 7,215 & 5,491 & 6,459 & 8,069 & 8,409 & 8,987 & 8,828 \\
\hline 588,4 & 4,129 & 4,922 & 6,316 & 6,589 & 6,984 & 6,906 & 5,231 & 6,153 & 7,702 & 8,061 & 8,609 & 8,439 \\
\hline 686,5 & 3,929 & 4,676 & 6,013 & 6,312 & 6,675 & 6,586 & 4,970 & 5,831 & 7,324 & 7,706 & 8,212 & 8,050 \\
\hline 784,5 & 3,721 & 4,431 & 5,711 & 6,027 & 6,365 & 6,266 & 4,728 & 5,544 & 6,980 & 7,385 & 7,850 & 7,680 \\
\hline
\end{tabular}

Table 2. - Parameter $\left(\bar{d}-r_{i}\right)$ values for ions at different temperatures and pressures

\begin{tabular}{|c|c|c|c|c|c|c|c|c|c|c|c|c|}
\hline \multirow{3}{*}{$\begin{array}{c}\mathrm{P}, \\
\mathrm{MPa}\end{array}$} & \multicolumn{12}{|c|}{$\left(\bar{d}-r_{i}\right) \cdot 10^{10}, \mathrm{~m}$} \\
\hline & \multicolumn{6}{|c|}{$298,15 \mathrm{~K}$} & \multicolumn{6}{|c|}{$323,15 \mathrm{~K}$} \\
\hline & $\mathrm{Li}^{+}$ & $\mathrm{Na}^{+}$ & $\mathrm{K}^{+}$ & $\mathrm{Cs}^{+}$ & $\mathrm{Cl}^{-}$ & $\mathrm{Br}^{-}$ & $\mathrm{Li}^{+}$ & $\mathrm{Na}^{+}$ & $\mathrm{K}^{+}$ & $\mathrm{Cs}^{+}$ & $\mathrm{Cl}^{-}$ & $\mathrm{Br}^{-}$ \\
\hline 0,0981 & 1,59 & 0,85 & $-0,08$ & $-0,46$ & $-0,61$ & $-0,79$ & 1,60 & 0,90 & 0,01 & $-0,35$ & $-0,53$ & $-0,70$ \\
\hline 98,1 & 1,58 & 0,84 & $-0,09$ & $-0,46$ & $-0,62$ & $-0,80$ & 1,56 & 0,86 & $-0,02$ & $-0,37$ & $-0,56$ & $-0,73$ \\
\hline 196,1 & 1,54 & 0,80 & $-0,12$ & $-0,49$ & $-0,65$ & $-0,82$ & 1,51 & 0,83 & $-0,04$ & $-0,41$ & $-0,59$ & $-0,76$ \\
\hline 294,2 & 1,50 & 0,77 & $-0,14$ & $-0,52$ & $-0,67$ & $-0,85$ & 1,47 & 0,79 & $-0,07$ & $-0,43$ & $-0,62$ & $-0,79$ \\
\hline 392,3 & 1,45 & 0,74 & $-0,17$ & $-0,55$ & $-0,70$ & $-0,87$ & 1,43 & 0,76 & $-0,10$ & $-0,47$ & $-0,65$ & $-0,82$ \\
\hline 490,3 & 1,41 & 0,71 & $-0,19$ & $-0,58$ & $-0,73$ & $-0,89$ & 1,38 & 0,73 & $-0,12$ & $-0,50$ & $-0,67$ & $-0,84$ \\
\hline 588,4 & 1,36 & 0,67 & $-0,22$ & $-0,61$ & $-0,75$ & $-0,92$ & 1,34 & 0,70 & $-0,14$ & $-0,53$ & $-0,70$ & $-0,86$ \\
\hline 686,5 & 1,32 & 0,64 & $-0,24$ & $-0,64$ & $-0,78$ & $-0,94$ & 1,30 & 0,67 & $-0,17$ & $-0,55$ & $-0,73$ & $-0,89$ \\
\hline 784,5 & 1,27 & 0,61 & $-0,26$ & $-0,67$ & $-0,81$ & $-0,97$ & 1,26 & 0,64 & $-0,19$ & $-0,59$ & $-0,75$ & $-0,91$ \\
\hline
\end{tabular}


ISSN 2708-5252 (online)

\begin{tabular}{|c|c|c|c|c|c|c|c|c|c|c|c|c|}
\hline \multirow{3}{*}{$\begin{array}{c}\mathrm{P} \\
\mathrm{MPa}\end{array}$} & \multicolumn{12}{|c|}{$\left(\bar{d}-\mathrm{r}_{\mathrm{i}}\right) \cdot 10^{10}, \mathrm{~m}$} \\
\hline & \multicolumn{6}{|c|}{$348,15 \mathrm{~K}$} & \multicolumn{6}{|c|}{$373,15 \mathrm{~K}$} \\
\hline & $\mathrm{Li}^{+}$ & $\mathrm{Na}^{+}$ & $\mathrm{K}^{+}$ & $\mathrm{Cs}^{+}$ & $\mathrm{Cl}^{-}$ & $\mathrm{Br}^{-}$ & $\mathrm{Li}^{+}$ & $\mathrm{Na}^{+}$ & $\mathrm{K}^{+}$ & $\mathrm{Cs}^{+}$ & $\mathrm{Cl}^{-}$ & $\mathrm{Br}^{-}$ \\
\hline 0,0981 & 1,58 & 0,92 & 0,09 & $-0,26$ & $-0,47$ & $-0,64$ & 1,56 & 0,94 & 0,15 & $-0,19$ & $-0,42$ & $-0,58$ \\
\hline 98,1 & 1,53 & 0,88 & 0,05 & $-0,30$ & $-0,51$ & $-0,68$ & 1,50 & 0,89 & 0,11 & $-0,24$ & $-0,47$ & $-0,63$ \\
\hline 196,1 & 1,46 & 0,82 & 0,00 & $-0,35$ & $-0,56$ & $-0,72$ & 1,44 & 0,84 & 0,07 & $-0,29$ & $-0,51$ & $-0,67$ \\
\hline 294,2 & 1,43 & 0,81 & $-0,01$ & $-0,37$ & $-0,58$ & $-0,74$ & 1,39 & 0,80 & 0,03 & $-0,32$ & $-0,55$ & $-0,70$ \\
\hline 392,3 & 1,38 & 0,77 & $-0,04$ & $-0,41$ & $-0,61$ & $-0,77$ & 1,35 & 0,77 & 0,00 & $-0,36$ & $-0,59$ & $-0,74$ \\
\hline 490,3 & 1,35 & 0,74 & $-0,07$ & $-0,44$ & $-0,64$ & $-0,79$ & 1,31 & 0,74 & $-0,03$ & $-0,39$ & $-0,62$ & $-0,76$ \\
\hline 588,4 & 1,31 & 0,70 & $-0,09$ & $-0,47$ & $-0,67$ & $-0,82$ & 1,26 & 0,71 & $-0,05$ & $-0,43$ & $-0,64$ & $-0,79$ \\
\hline 686,5 & 1,27 & 0,67 & $-0,12$ & $-0,50$ & $-0,70$ & $-0,85$ & 1,23 & 0,68 & $-0,08$ & $-0,46$ & $-0,67$ & $-0,81$ \\
\hline 784,5 & 1,23 & 0,64 & $-0,14$ & $-0,53$ & $-0,72$ & $-0,87$ & 1,19 & 0,65 & $-0,10$ & $-0,48$ & $-0,69$ & $-0,84$ \\
\hline \multirow{3}{*}{$\begin{array}{c}\mathrm{P}, \\
\mathrm{MPa}\end{array}$} & \multicolumn{12}{|c|}{$\left(d-\mathrm{r}_{\mathrm{i}}\right) \cdot 10^{10}, \mathrm{~m}$} \\
\hline & \multicolumn{6}{|c|}{$398,15 \mathrm{~K}$} & \multicolumn{6}{|c|}{$423,15 \mathrm{~K}$} \\
\hline & $\mathrm{Li}^{+}$ & $\mathrm{Na}^{+}$ & $\mathrm{K}^{+}$ & $\mathrm{Cs}^{+}$ & $\mathrm{Cl}^{-}$ & $\mathrm{Br}^{-}$ & $\mathrm{Li}^{+}$ & $\mathrm{Na}^{+}$ & $\mathrm{K}^{+}$ & $\mathrm{Cs}^{+}$ & $\mathrm{Cl}^{-}$ & $\mathrm{Br}^{-}$ \\
\hline 0,0981 & 1,54 & 0,96 & 0,21 & $-0,13$ & $-0,38$ & $-0,53$ & 1,52 & 0,97 & 0,26 & $-0,08$ & $-0,34$ & $-0,48$ \\
\hline 98,1 & 1,46 & 0,89 & 0,15 & $-0,19$ & $-0,44$ & $-0,59$ & 1,43 & 0,90 & 0,19 & $-0,15$ & $-0,41$ & $-0,55$ \\
\hline 196,1 & 1,40 & 0,84 & 0,10 & $-0,25$ & $-0,49$ & $-0,64$ & 1,37 & 0,84 & 0,14 & $-0,21$ & $-0,47$ & $-0,60$ \\
\hline 294,2 & 1,35 & 0,80 & 0,07 & $-0,29$ & $-0,53$ & $-0,67$ & 1,31 & 0,80 & 0,10 & $-0,26$ & $-0,51$ & $-0,65$ \\
\hline 392,3 & 1,31 & 0,76 & 0,04 & $-0,33$ & $-0,56$ & $-0,70$ & 1,26 & 0,76 & 0,06 & $-0,30$ & $-0,55$ & $-0,68$ \\
\hline 490,3 & 1,26 & 0,73 & 0,01 & $-0,36$ & $-0,60$ & $-0,74$ & 1,22 & 0,72 & 0,03 & $-0,34$ & $-0,59$ & $-0,72$ \\
\hline 588,4 & 1,22 & 0,70 & $-0,02$ & $-0,40$ & $-0,63$ & $-0,76$ & 1,18 & 0,69 & 0,00 & $-0,38$ & $-0,62$ & $-0,74$ \\
\hline 686,5 & 1,18 & 0,67 & $-0,05$ & $-0,43$ & $-0,65$ & $-0,79$ & 1,14 & 0,66 & $-0,02$ & $-0,41$ & $-0,65$ & $-0,77$ \\
\hline 784,5 & 1,15 & 0,64 & $-0,07$ & $-0,46$ & $-0,68$ & $-0,81$ & 1,11 & 0,63 & $-0,05$ & $-0,44$ & $-0,67$ & $-0,80$ \\
\hline
\end{tabular}

\begin{tabular}{|c|c|c|c|c|c|c|}
\hline \multicolumn{7}{|c|}{ Table 3. -Water viscosity at different T and P [15] } \\
\hline $\mathrm{P}$, \\
\cline { 2 - 7 } & $298,15 \mathrm{~K}$ & $323,15 \mathrm{~K}$ & $348,15 \mathrm{~K}$ & $373,15 \mathrm{~K}$ & $398,15 \mathrm{~K}$ & $423,15 \mathrm{~K}$ \\
\hline 0,0981 & 0,8903 & 0,5471 & 0,3784 & 0,2831 & 0,2220 & 0,1832 \\
\hline 98,1 & 0,8780 & 0,5670 & 0,4033 & 0,3025 & 0,2437 & 0,2030 \\
\hline 196,1 & 0,9198 & 0,5978 & 0,4300 & 0,3266 & 0,2667 & 0,2230 \\
\hline 294,2 & 0,9731 & 0,6333 & 0,4553 & 0,3516 & 0,2860 & 0,2420 \\
\hline 392,3 & 1,0440 & 0,6761 & 0,4898 & 0,3764 & 0,3060 & 0,2610 \\
\hline 490,3 & 1,1270 & 0,7235 & 0,5228 & 0,4021 & 0,3300 & 0,2820 \\
\hline 588,4 & 1,2270 & 0,7789 & 0,5602 & 0,4303 & 0,3530 & 0,3020 \\
\hline 686,5 & 1,3370 & 0,8395 & 0,6042 & 0,4590 & 0,3780 & 0,3240 \\
\hline 784,5 & 1,4620 & 0,9084 & 0,6505 & 0,4909 & 0,4060 & 0,3470 \\
\hline
\end{tabular}

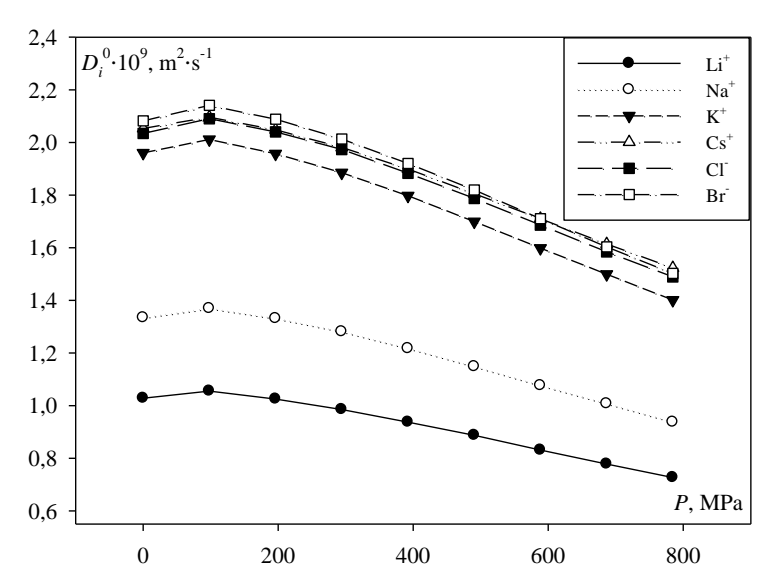

Fig. 1 Dependence of ions diffusion coefficient $D_{i}^{0}$ on pressure at $298.15 \mathrm{~K}$

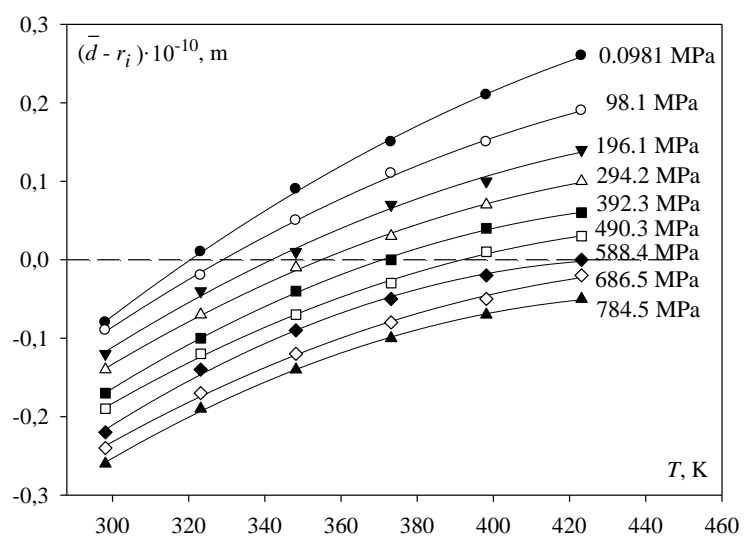

Fig. 2 Polytherms $\left(\bar{d}-r_{i}\right)$ for $\mathrm{K}^{+}$cation in water at different pressures 


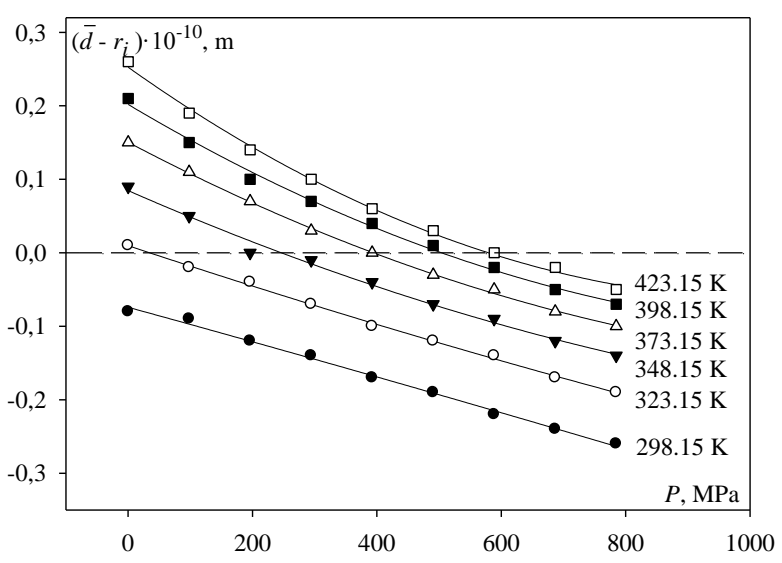

Fig. 3 Polybars $\left(\bar{d}-r_{i}\right)$ for $\mathrm{K}^{+}$cation in water at different pressures

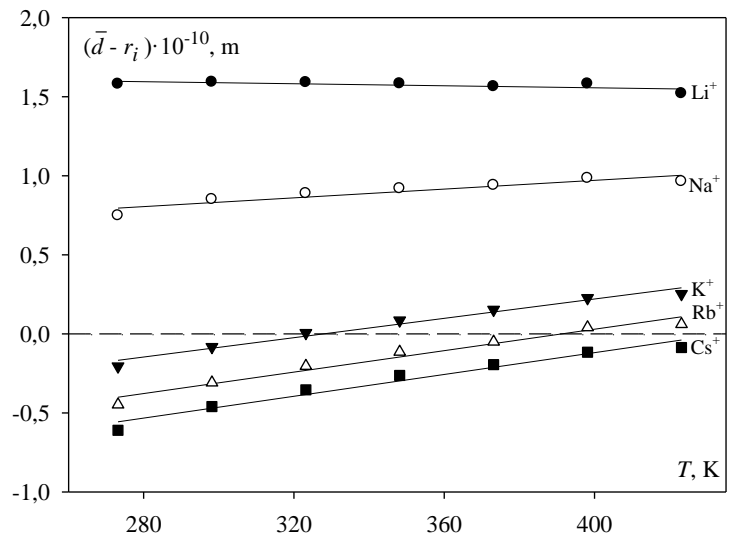

Fig. 4 Polytherms $\left(\bar{d}-r_{i}\right)$ for alkali metal cations in water at saturated vapor pressure

Table 4. - Temperature of transition $\left(\mathrm{T}_{\text {trans }}\right)$ from negative to positive hydration for $\mathrm{K}^{+}$cation

\begin{tabular}{|c|c|c|c|c|c|c|c|}
\hline $\mathrm{P}, \mathrm{\kappa} \Gamma / \mathrm{cm}^{2}$ & 0,0981 & 98,1 & 196,1 & 294,2 & 392,3 & 490,3 & 588,4 \\
\hline $\mathrm{T}_{\text {trans },} \mathrm{K}$ & $\simeq 320$ & $\simeq 330$ & $\simeq 348$ & $\simeq 354$ & $\simeq 373$ & $\simeq 393$ & $\simeq 423$ \\
\hline
\end{tabular}

Table 5. - Pressure of transition $\left(\mathrm{P}_{\text {trans }}\right)$ from negative to positive hydration for $\mathrm{K}^{+}$cation

\begin{tabular}{|c|c|c|c|c|c|c|}
\hline $\mathrm{T}, \mathrm{K}$ & 298,15 & 323,15 & 348,15 & 373,15 & 398,15 & 423,15 \\
\hline $\mathrm{P}_{\text {trans }}, \mathrm{MPa}$ & - & $\simeq 33$ & $\simeq 229$ & $\simeq 392$ & $\simeq 523$ & $\simeq 588$ \\
\hline
\end{tabular}

Discussion. When discussing the results of the effect of pressure and temperature on the short-range hydration of monatomic singly charged ions, the latter was considered, following [1], not as the binding of a number of solvent molecules by ions, but the effect on the mobility of water molecules in their immediate surroundings. Since we know little about the mechanism of the effect of ions on the solvent, for clarity of the model, we postulate that when a negatively solvated ion (chaotrope) is placed in water, its radius remains equal to the structural one $\left(r_{i}\right)$, and the ion shifts in a characteristic time $(\tau)$ by an amount of $\bar{d}$ less than its own radius $\bar{d}<r_{i}$. If the ion was acted upon by a force retarding its motion, caused only by the viscosity of the solvent, then in accordance with the Stokes-Einstein law $\bar{d}=r_{i}$. Consequently, a decrease in comparison with $r_{i}$ indicates its additional inhibition.

An indirect confirmation of the latter is the increase with increasing temperature for negatively solvated ions (see Table 2). In this case, the value can reach the value of its structural radius (Table $2, \mathrm{~K}^{+}$ion at $T=348.15$; 373.15; $423.15 \mathrm{~K})$.

According to Samoilov [1], such an additional brake is the spatial network of $\mathrm{H}$-bonds in the solvent, which inhibits (in the case of chaotrope ions,) the exchange between the $\mathrm{H}_{2} \mathrm{O}$ molecules in the bulk and the primary solvation shell (PSS), which actually causes a decrease. In the case of negatively solvated ions, the ion-molecule (IM) bonds are weaker than the molecule-molecule (MM) bonds [1]. In this case, the mobility of water molecules in the PSS ion is accelerated. The acceleration of water molecules by chaotropes, on the one hand, creates favorable conditions for their free movement in solution, and, on the other hand, the inhibitory effect of the network of $\mathrm{H}$-bonds in the solvent. As long as the condition $\left(\bar{d}-r_{i}\right)<0$ is observed for the ion, destruction of the structure will prevail near the latter, and the process of ordering of its molecules will prevail in the volume of the solvent.

In the case of kosmotrope ions $\left(\bar{d}-r_{i}\right)>0$, the IM bonds are stronger than the MM bonds [2], while the mobility of water molecules in the PSS ion slows down, and the $\bar{d}$ value increases due to the effect of the $\mathrm{H}$-bond network on the exchange of water molecules. It is interesting to note the opposite effect of chaotropes and kosmotropes on the translational motion of water molecules near ions and in its volume. Acceleration of the mobility of water molecules near chaotropic ions leads to their additional deceleration by the $\mathrm{H}$-bond network, and its deceleration under the influence of kosmotrope ions is accompanied, on the contrary, by a weakening of the inhibitory effect on the ion of the $\mathrm{H}$-bond network. 
The opposite nature of the influence of temperature and pressure on the $\left(\bar{d}-r_{i}\right)$ parameter as the measure of the influence of ion on the solvent is apparently associated with their different effect on short-range hydration, determined by the IM and MM interactions. In the region of low temperatures, an increase in pressure, like in temperature, has a destructive effect on the structure of water in solution, which is consistent with a change in the properties of water and aqueous solutions [10].

Our results and conclusions regarding the nature of short-range hydration of singly charged ions are consistent with the data of [20], in which a structural and dynamic study of aqueous clusters of $\mathrm{Na}^{+}, \mathrm{K}^{+}$, and $\mathrm{Cs}^{+}$ ions was carried out by molecular dynamics modeling. The authors of [20] come to the conclusion that near the $\mathrm{K}^{+}$and $\mathrm{Cs}^{+}$ions there is a significant increase in the mobility of water molecules in comparison with the $\mathrm{Na}^{+}$ ion. The increase in mobility is associated with a larger number of "bifurcate" bonds in the first hydration sphere and in the intermediate region between the hydration shells of $\mathrm{K}^{+}$and $\mathrm{Cs}^{+}$ions. In this case, according to [20], there is, as it were, a transfer of "bifurcate" bonds from the first hydration sphere to the intermediate region when moving to clusters containing a larger number of water molecules. The very presence of «bifurcate» bonds is considered in this case as defects in the network of $\mathrm{H}-$ bonds, which create sufficiently large singly charged ions.

Summary. Chaotropes affect the water structure like temperature growth does, while the kosmotropes influence is similar to the pressure rising effect. In contrast to the temperature growing impact, an increase in pressure leads to a weakening of short-range solvation at $\mathrm{T}>320 \mathrm{~K}$.

\section{References}

1. Самойлов О.Я. Структура водных растворов электролитов и гидратация ионов. М.: Изд-во АН СССР, 1957. 183 с.

2. Collins K.D. Charge density-dependent strength of hydration and biological structure. Biophys. J., 1997. V.72, № 1. P. 65-76.

3. Bulavin V. I., V'yunnik I. N., Kramarenko A. V. Kinetic solvation and electrical conductance of proton in infinitely diluted solutions of hydrogen halides in primary alcohols and in water: influence of temperature and solvent. J. Mol. Liquids, 2017. V. 242 . P. $1296-$ 1309.

4. Захаров С. Д., Мосягина И.В. Кластерная структура воды (Обзор). - Препринт: физический ин-т им. П.Н. Лебедева РАН. M., 2011.24 c.

5. Родникова М.Н., Чумаевский Н.А. О пространственной сетке водородных связей в жидкостях и растворах. Ж. структ. химии, 2006. T. 47. Прил. S154-S151.

6. Саркисов Г.Н. Структурные модели воды. УФН, 2006. Т. 146. С. $833-845$

7. Неволина Н.А., Самойлов О.Я., Сейфер А.Л. Зависимость ближней гидратации ионов $\mathrm{Na}^{+}, \mathrm{K}^{+}$и $\mathrm{NH}_{4}^{+}$от давления. Ж. структ. химии, 1969. Т.10, № 2. С. 203-207.
8. Самойлов О.Я., Сейфер А.Л. , Неволина Н.А. Влияние давления на гидратацию $\mathrm{Na}^{+}$и $\mathrm{K}^{+}$в неводных растворах из данных по адиабатической сжимаемости. Ж. структ. химии,1973. Т.14, № 2. С. 360-361.

9. Самойлов О.Я. Координационное число и трансляционное движение частиц в водных растворах электролитов. Докл. АН CCCP, 1959. T. 126. C. 330-333.

10. Horne R.A. A modification of Walden's rule appricable to the electrical conductance of aqueous electrolytic solutions under pressure. Nature, 1963. V. 200. P.418-419.

11. Nakahara M., Shimizu K., Osugi J. Ionic solutions under high presure. III. Pressure and temperature effects on the mobilities of $\mathrm{K}^{+}$ and $\mathrm{Cl}^{-}$ions. Rev. Phys. Chem. Jap.,1972. V. 42. P.12-24.

12. Торяник А.И. Молекулярная подвижность и структура водных систем: Автореф. дис. ... д-ра хим. наук. Москва, 1974. 46 с.

13. Bulavin V.I., V'yunyk I.M., Lazareva Y.I. Diffusion and microscopic characteristics of singly charged ion transfer in extremely diluted aqueous solutions. Ukrainian Journal of Physics, 2017. V. 62, № 9. Р. 769-778

14. Булавін B.І., В’юник I.М., Крамаренко А.В., Русінов О.І., Мінаков В.О. Особливості встановлення ближньої сольватації іонів тетраалкіламонію в розчинниках з просторовою сіткою Н-зв'язків. Вісник НТУ «ХПІ». Серія: Хімія, хімічна технологія та екологія, 2020. № 1 . С. 28-32.

15. Ларионов Э.Г. К расчету предельной электропроводности индивидуальных ионов при высоких температурах и давлениях. Изв. СО АН СССР. Сер. хим., 1976. №6 С. 3-9.

16. Смоляков Б.С. Предельная эквивалентная электропроводность ионов в воде при температурах до $200{ }^{\circ} \mathrm{C}$. Вестн. Харьк. ун-та, 1976. № 139: Вопросы электрохимии. С.37-39.

17. Краткий справочник физико-химических величин. / А.А. Равдель, А.М. Пономарева. Изд-во Спец. Лит., 1983. 232 с.

18. Вдовенко В.М., Гуриков Ю.В., Легнин Е.К. Термодинамика двухструктурной модели воды. І. О структуре тяжелой воды. Ж. структур. химии, 1966. Т.7. С. 819-824.

19. Самойлов О.Я., Носова Т.А. Структурные особенности воды. Ж. структур. химии,, 1965. Т.6. С. 798-808.

20. Гайгер А., Родникова М.Н., Засыпкин С.А. Структурное и динамическое исследование водных кластеров ионов $\mathrm{Na}^{+}, \mathrm{K}^{+}$и $\mathrm{Cs}^{+}$Ж. физ. химии, 1995. Т. 69. № 7. С. 1299-1305.

\section{References (transliterated)}

1. Samoilov O. Y. Struktura vodnyh rastvorov jelektrolitov i gidratacija ionov, USSR Acad. of Sciences Publ., Moscow, 1957. $183 \mathrm{p}$.

2. Collins K.D. Charge density-dependent strength of hydration and biological structure. Biophys. J., 1997. V.72, № 1. P. 65-76.

3. Bulavin V. I., V'yunnik I. N., Kramarenko A. V. Kinetic solvation and electrical conductance of proton in infinitely diluted solutions of hydrogen halides in primary alcohols and in water: influence of temperature and solvent. J. Mol. Liquids, 2017. V. 242 . P. $1296-$ 1309.

4. Klasternaya struktura vody (obzor) / S.D. Zakharov, I.V. Mosyagina. Moskva: FIAN, 2011. 24 s. (Preprint).

5. Rodnikova M.N., Chumaevskiy N.A. O prostranstvennoy setke vodorodnyih svyazey v zhidkostyah i rastvorah. Zh. strukt. himii, 2006. T. 47. Pril. S154-S151

6. Sarkisov G.N. Strukturnye modeli vody //Uspekhi fiz. nauk. 2006. - T. 146. - № 8. - S. 833 - 845.

7. Nevolina N.A., Samoilov O.Ya., Seyfer A.L. Zavisimost' blizhney gidratatsii ionov $\mathrm{Na}+\mathrm{K}+\mathrm{i} \mathrm{NH} 4+$ ot davleniya. Zh. strukt. himii,1969. T.10, № 2. S. 203-207.

8. Samoilov O.Ya., Seyfer A.L., Nevolina N.A. Vliyanie davleniya na 
gidratatsiyu $\mathrm{Na}+\mathrm{i} \mathrm{K}+\mathrm{v}$ nevodnyih rastvorah iz dannyih po adiabaticheskoy szhimaemosti. Zh. strukt. himii,1973. T.14, № 2. S. 360-361.

9. Samoylov O.Ya. Koordinatsionnoe chislo i translyatsionnoe dvizhenie chastits $\mathrm{v}$ vodnyih rastvorah jelektrolitov. Dokl. AN SSSR, 1959. T. 126. S. 330-333.

10. Horne R.A. A modification of Walden's rule appricable to the electrical conductance of aqueous electrolytic solutions under pressure. Nature, 1963. V. 200. P.418-419.

11. Nakahara M., Shimizu K., Osugi J. Ionic solutions under high presure. III. Pressure and temperature effects on the mobilities of $\mathrm{K}+$ and $\mathrm{Cl}-$ ions. Rev. Phys. Chem. Jap.,1972. V. 42. P.12-24.

12. Toryanik A.I. Molekulyarnaya podvizhnost' i struktura vodnyih sistem: Avtoref. dis. ... d-ra him. nauk. Moskva, 1974. 46 s.

13. Bulavin V.I., V'yunyk I.M., Lazareva Y.I. Diffusion and microscopic characteristics of singly charged ion transfer in extremely diluted aqueous solutions. Ukrainian Journal of Physics, 2017. V. 62, № 9. P. 769-778.

14. Bulavin V.I., V'јunyк I.M., Кramarenко A.V., Rusinov O.I., Міnакоv V.O. Osoblivosti vstanovlennya blizhnoyi solvatatsiyi ioniv tetraalkilamoniyu $\mathrm{v}$ rozchinnikah $\mathrm{z}$ prostorovoyu sitkoyu $\mathrm{H}-$ zv'yazkiv/ V.I. Bulavin// Visnyk Nazional'nogo technichnogo universitetu «KhPI». Serija: Khimija, khimichna technologija ta ekologija. 2020. №1. S. 28-32.

15. Larionov E.G. K raschetu predel'noj elektroprovodnosti individual'nych ionov pri vysokikh temperaturach i davleniyakh // Izv. SO AN SSSR. Ser. khim., 1976. №6 S. 3-9.

16. Smolyakov B.S. Predel'naya jekvivalentnaya jelektroprovodnost' ionov v vode pri temperaturah do 200 0C. Vestn. Hark. un-ta, 1976. № 139: Voprosyi elektrohimii. S.37-39.

17. Kratkij spravochnik fiziko-khimicheskikh velichin / A.A. Ravdel', A.M. Ponomareva. Izd-vo Spez. Lit., 1983. 232 s.

18. Vdovenko V.M., Gurikov Yu.V., Legnin E.K. Termodinamika dvukhstrukturnoj modeli vody. I. O structure tyazheloj vody //Zh. Struktutrn. khimii, 1966. T. 7. № 6. S. $819-824$.

19. Sамоjlov O.Ya., Nosova T.A. Strukturnye osobennosti vody// Zh. Struktutrn. khimii, 1965. T. 6. № 5. S. $798-808$.

20. Gayger A., Rodnikova M.N., Zasyipkin S.A. Strukturnoe i dinamicheskoe issledovanie vodnyih klasterov ionov $\mathrm{Na}+\mathrm{K}+\mathrm{i}$ Cs+. Zh. fiz. himii, 1995. T. 69. № 7. S. 1299-1305.

Надійшла (received) 15.01.2021

\section{Відомості про авторів/Сведения об авторах/ About the Authors}

Булавін Віктор Іванович (Булавин Виктор Иванович, Bulavin Viktor Ivanovych) - кандидат хімічних наук, професор НТУ «ХПІ», завідувач кафедри загальної та неорганічної хімії НТУ «ХПІ», м. Харків, Україна; Тел. +38(57)707-64-92 ORCID: https://orcid.org/0000-0002-3451-1613; e-mail: bulavin@kpi.kharkov.ua.

В’юник Іван Миколайович (Вьюнник Иван Николаевич, V'unik Ivan Nikolajevych) - доктор хімічних наук, професор, завідувач кафедри неорганічної хімії ХНУ ім. В.Н. Каразіна, м. Харків, Україна; Тел. +38(57)707-54-83 e-mail: vladdal@gmail.com.

Крамаренко Андрій Вікторович (Крамаренко Андрей Викторович, Kramarenko Andrii Viktorovych)старший викладач кафедри загальної та неорганічної хімії НТУ «ХПІ», м. Харків, Україна; Тел. +38(57)70768-32; e-mail: avkramar@gmail.com.

Русінов Олександр Іванович (Русинов Александр Иванович, Rusinov Alexandr Ivanovych) - кандидат технічних наук, доцент, доцент кафедри загальної та неорганічної хімії НТУ «ХПІ», м. Харків, Україна; Тел. +38(57)707-61-20 e-mail: supre-santa@mail.ru. 